\title{
CORRECTION
}

View Article Online

View Journal I View Issue

\section{D) Check for updates Correction: The development of a full range analytical interatomic potential}

Cite this: Phys. Chem. Chem. Phys.,

$2021,23,4453$

X. W. Sheng ${ }^{a}$ and K. T. Tang ${ }^{\star b}$

Correction for 'The development of a full range analytical interatomic potential' by X. W. Sheng et al.,

DOI: $10.1039 / \mathrm{d} 1 \mathrm{cp} 90032 \mathrm{c}$

Phys. Chem. Chem. Phys., 2021, DOI: 10.1039/d0cp04083e.

rsc.li/pccp

The authors would like to update the details of ref. 64 , which has now been published. The updated citation details are shown below as ref. 1.

The Royal Society of Chemistry apologises for these errors and any consequent inconvenience to authors and readers.

\section{References}

1 X. W. Sheng, J. P. Toennies and K. T. Tang, Phys. Rev. Lett., 2020, 125, 253402.

${ }^{b}$ Department of Physics, Pacific Lutheran University, Tacoma, Washington, 98447, USA. E-mail: tangka@plu.edu 